\title{
PERUBAHAN UKURAN PUPIL PADA TINGKAT ATENSI
}

\author{
Fadilla Zennifa $^{1}$, Keiji Iramina $^{2}$ \\ ${ }^{1}$ Independent researcher \\ ${ }^{2}$ Graduate School of systems Life Sciences, Kyushu University \\ thesisfadilla@gmail.com, Iramina@inf.kyushu-u.ac.jp
}

\begin{abstract}
Atensi adalah suatu kondisi ketika seseorang berkonsentrasi pada tugas tertentu sambil mengabaikan informasi lainnya. Penelitian pada artikel ini mengusulkan penggunaan pupilometri untuk evaluasi tingkat atensi. Pupilometri didefinisikan sebagai pengukuran perubahan ukuran pupil. Dalam studi ini, tingkat atensi didasarkan atas laporan dari peserta (self assessment) dalam stimulasi yang berdurasi 10 detik. Melalui penelitian ini, didapatkan hasil bahwa ukuran pupil menunjukkan tidak ada perbedaan signifikan di permulaan 6 detik stimulasi $(\mathrm{P}=0.4776), \mathrm{P}>0.05$. Perbedaan signifikan terjadi pada 4 detik terakhir dari stimulasi $\mathrm{P}<0.05$.
\end{abstract}

Keywords: Pupilometri, Atensi.

Received 3 October 2020 Accepted 11 January 2021

\section{PENDAHULUAN}

Pupilometri adalah pengukuran reaktivitas dan ukuran pupil. Ini juga digunakan dalam psikologi [1]. Pupilometri berkaitan dengan perubahan ukuran pupil. Beberapa penelitian menyatakan bahwa diameter ukuran pupil dapat digunakan sebagai penanda cognitive load dan performa atensi [2-8]. Sebuah studi oleh [9] menyebutkan bahwa ukuran pupil dapat digunakan untuk mengevaluasi fokus atensi. Penelitian lainnya [10], menyimpulkan bahwa pelebaran pupil tidak hanya memberikan indeks upaya atensi secara keseluruhan tetapi juga didasarkan pada waktu perubahan stimulus selama atensi (tetapi tidak selama berkhayal). Penemuan tersebut menunjukkan bahwa dilatasi pupil menghasilkan pembacaan dinamis dari pemrosesan informasi secara sadar. Temuan mereka kemudian telah diduplikasi oleh peneliti lainnya [11], yang menunjukkan kopling stimulus-pupil dari cerminan pemrosesan kognitif daring di luar perolehan sensorik. Penggunaan pupilometri untuk penelitian atensi juga digunakan oleh Naber et al [12]. Dalam penelitiannya, mereka menggunakan metode pupil frequency tagging (PFT) untuk melihat hubungan antara pusat kortikal dengan atensi selektif visual. Mereka menyimpulkan bahwa sinyal amplitudo tanggapan pupil mengikuti alokasi atensi visual fokal dan pengkodean rangsangan [13].

\section{METODE PENELITIAN}

\section{Peserta}

Ada 18 peserta dalam percobaan di dalam penelitian ini. Semua peserta adalah mahasiswa Universitas Kyushu, dengan rentang usia 21 hingga 29 tahun $(23,5 \pm 2,18)$. Semua peserta memiliki fungsi penglihatan yang normal dan bebas dari penyakit syaraf; 15 tidak kidal, 1 peserta ambidextrous, dan 2 peserta kidal. Peserta diinstruksikan untuk tidak mengonsumsi kafein 2 jam sebelum percobaan karena dapat mempengaruhi HRV (Heart rate variability) [14-15]. Penelitian dilakukan dengan mengikuti prinsip etika Universitas Kyushu dan Deklarasi Helsinki. Persetujuan tertulis diperoleh dari masing-masing peserta sebelum percobaan. 


\section{Kondisi percobaan}

Percobaan berlangsung di ruangan yang remang-remang. Aktivitas perilaku peserta direkam dengan menggunakan kamera webcam (Logicool C270, Logitech, Switzerland) yang letaknya sekitar $57 \mathrm{~cm}$ di depan wajah peserta.

Tiga jenis stimulasi atensi digunakan, yaitu: Backward Digit Span (BDS) [16-21], forward digit span (FDS) [16-21] dan aritmatika [19]. Tugas ini terdiri dari tiga level. Level satu terdiri dari rangkaian 20 set empat digit, level dua: 20 set lima digit dan level tiga: 20 set enam digit. Sebagian besar pertanyaan dalam eksperimen ini relatif sederhana dan tidak memerlukan pengetahuan prasyarat atau keterampilan khusus. Namun, tingkat atensi dan kewaspadaan yang baik diperlukan untuk menghindari kesalahan yang mudah karena waktu respons dibatasi hingga 15 detik. Setiap uji coba dimulai dengan penyajian titik fiksasi putih di tengah dengan latar belakang gelap sampai mata peserta dapat diterima oleh pelacak mata. Selanjutnya, pertanyaan kognitif (mis., Sesi pengkodean) akan muncul selama 10 detik dan peserta diinstruksikan untuk menjawab dalam 15 detik. Digit akan muncul setiap 2,5 detik dalam level 4 digit, 2 detik dalam level 5 digit, dan 1,67 detik dalam level 6 digit. Setelah itu, peserta harus melaporkan tingkat atensinya dalam dua kondisi, tinggi atau rendah. Semua tugas kognitif diimbangi. Pengukuran dicatat setelah sesi latihan selesai. Tugas tersebut dapat dilihat pada Gambar1.

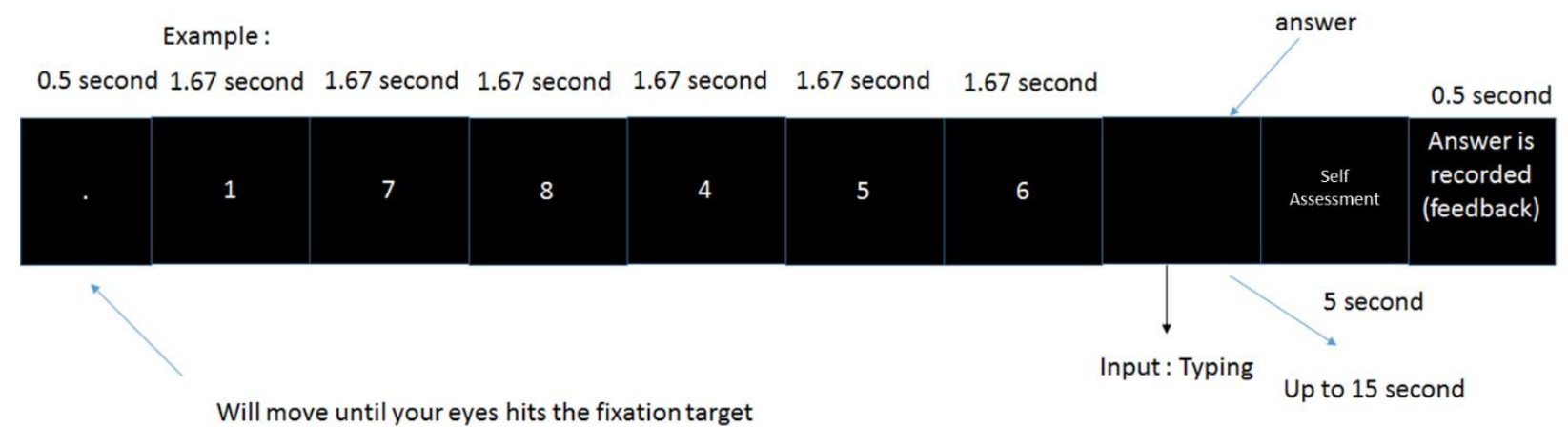

Gambar 1. Contoh dari sampel stimulus

\section{Perangkat Lunak dan Peralatan}

Dalam bab ini, monitor CRT 17 inci $(1024 \times 768)$ telah digunakan untuk menyajikan rangsangan. Pengujian dilakukan di ruangan yang remang-remang. Presentasi stimulus dilakukan dengan menggunakan perangkat lunak OpenSesame [22], menggunakan back end legacy untuk kontrol tampilan dan toolbox PyGaze [23] untuk mengintegrasikan ke pelacak mata. Kondisi penelitian dapat dilihat pada Gambar 2.

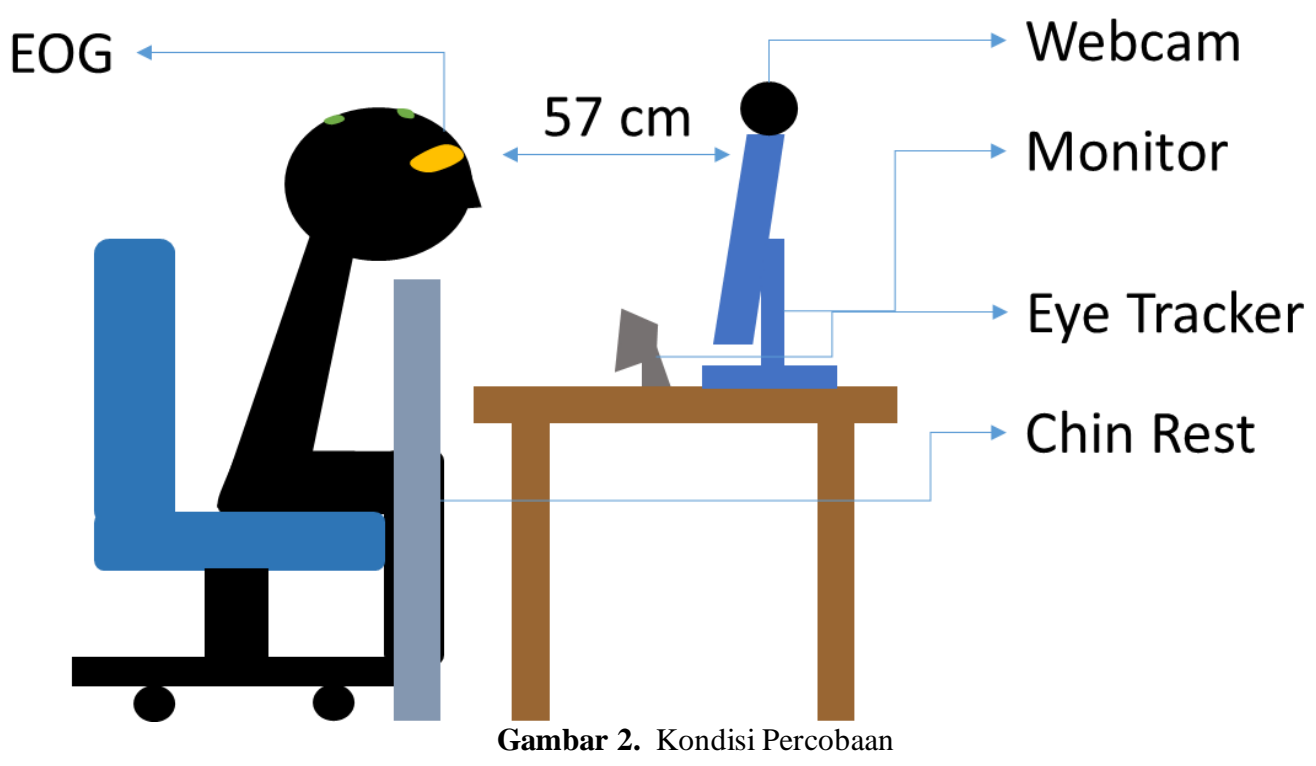


Sebelum memulai setiap tugas, peserta diposisikan di depan Eyetracker (EyeTribe versi 1, Kopenhagen, Denmark). Jarak mata peserta dari The EyeTribe diperkirakan $\sim 57 \mathrm{~cm}$. Para peserta diminta untuk menyandarkan kepala pada sandaran dagu. Dalam studi ini, kami mengkalibrasi dan memvalidasi sistem pelacakan mata untuk setiap peserta menggunakan matriks titik sembilan titik. Setelah validasi, Eyetracker yang telah tertanam dengan perangkat lunak OpenSesame memberi label pada setiap titik kalibrasi dengan kesalahan dalam derajat sudut visual antara pengukuran yang dikalibrasi dan divalidasi. Jika titik kalibrasi tidak melebihi $1^{\circ}$ (derajat) dan kesalahan titik tunggal terbesar tidak melebihi $1^{\circ}$, proses akan dilanjutkan. Sebelum setiap percobaan, kalibrasi ulang Eyetracker satu titik dilakukan.

\section{Analisis pupilometri}

Pupilometri berkaitan dengan perubahan ukuran pupil. Diameter ukuran pupil telah lama dikenal sebagai penanda beban kognitif dan kinerja atensi. Sebuah studi oleh [9] menyebutkan bahwa ukuran pupil dapat digunakan untuk melacak fokus atensi. Saat menggunakan Eyetracker untuk mencatat ukuran pupil, ada data yang hilang. Untuk mengatasi masalah tersebut, pada penelitian ini dilakukan interpolasi kubik spline ([9];[11];[23];[24]) dalam data kami untuk merekonstruksi sinyal, dan menghubungkan data yang hilang. Gambar 3 menunjukkan perbedaan sinyal sebelum interpolasi dan setelah interpolasi.
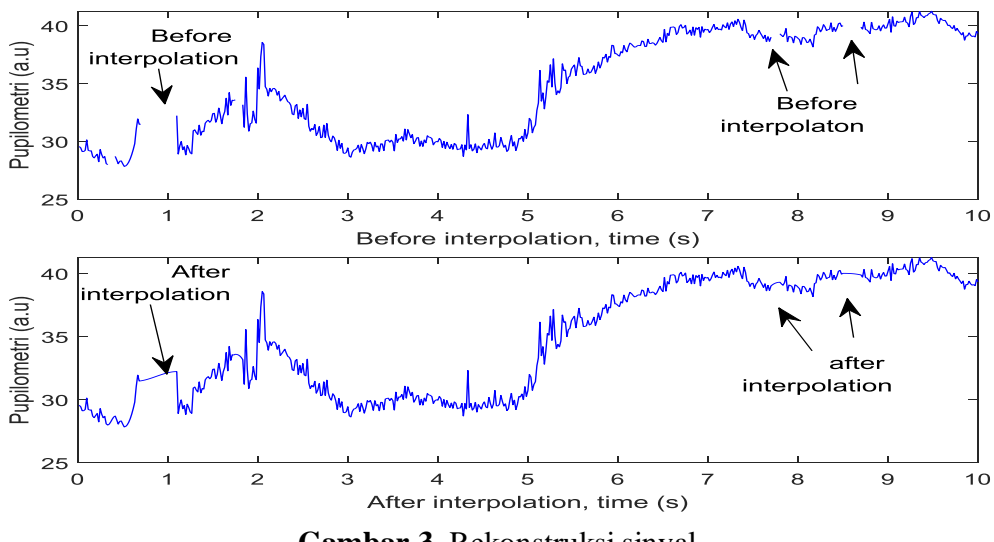

Gambar 3. Rekonstruksi sinyal

Dalam penelitian ini, pupilometri dianalisa menggunakan program yang ditulis di Matlab 2017b. Prosesnya dimulai dengan mendeteksi data yang hilang atau sinyal yang berukuran kurang dari 20 piksel akan diganti dengan $\mathrm{NaN}$ kemudian diterapkan metode interpolasi kubik untuk merekonstruksi data tersebut. Proses analisis dapat dilihat pada Gambar 4. 


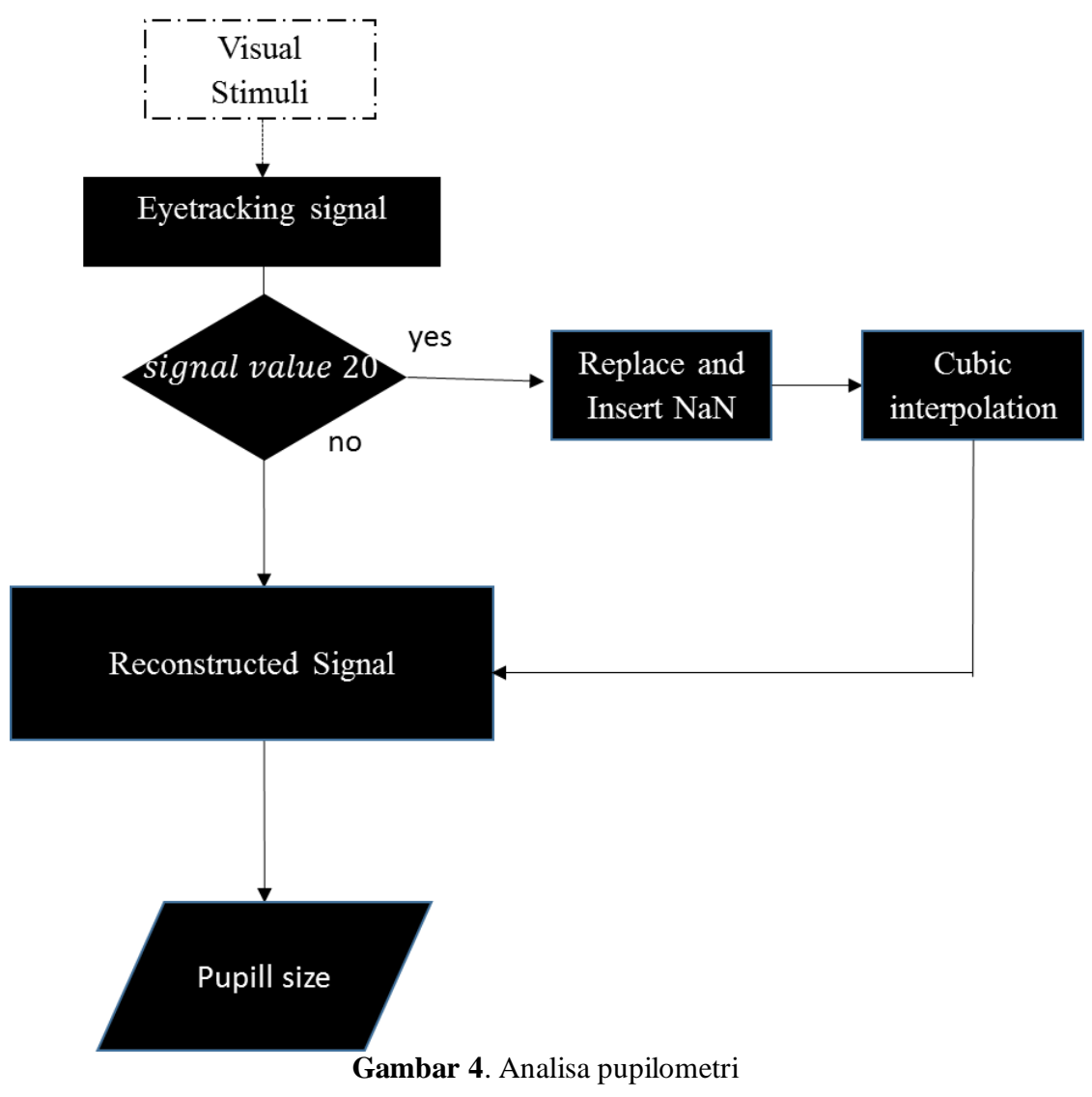

\section{HASIL DAN PEMBAHASAN}

\section{Hasil Pupilometri pada level atensi yang berbeda}

Pada penelitian ini, pupilometri dihitung berdasarkan analisis temporal dan klasifikasi data dilakukan berdasarkan laporan peserta (self assessment). Berdasarkan penyelidikan dalam penelitian ini, aktivitas pupilometri selama atensi tinggi (Gambar 5) dan atensi rendah (Gambar 6) memiliki karakteristik yang berbeda.

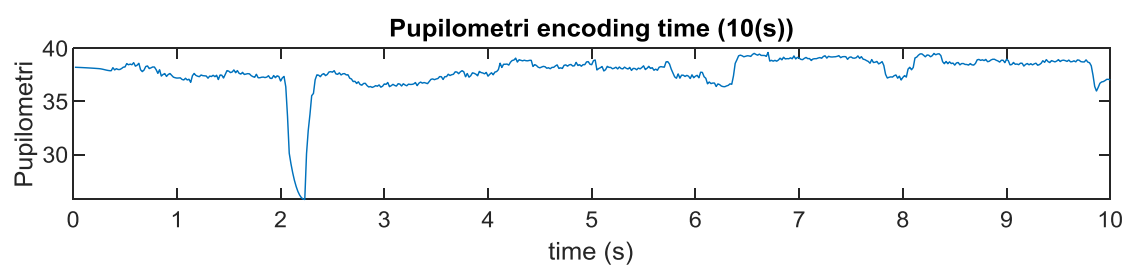

Gambar 5. Atensi tinggi pada setiap stimulasi

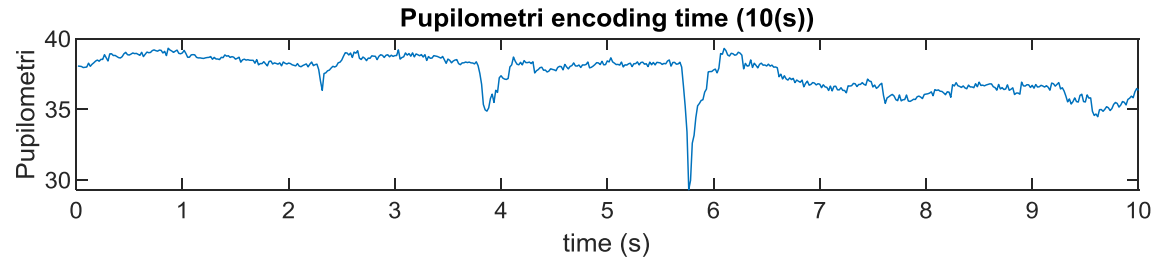

Gambar 6 Atensi rendah pada setiap stimulasi

Setelah menghitung data dari masing-masing partisipan pada setiap uji coba, ditemukan bahwa rata-rata ukuran pupil pada pupilometri cenderung menurun pada atensi yang rendah dan cenderung stabil pada atensi tinggi yang dianalisis secara temporal. Setelah itu, penelitian ini juga menemukan bahwa pupilometri dalam atensi tinggi memiliki ukuran yang lebih besar daripada atensi rendah. 


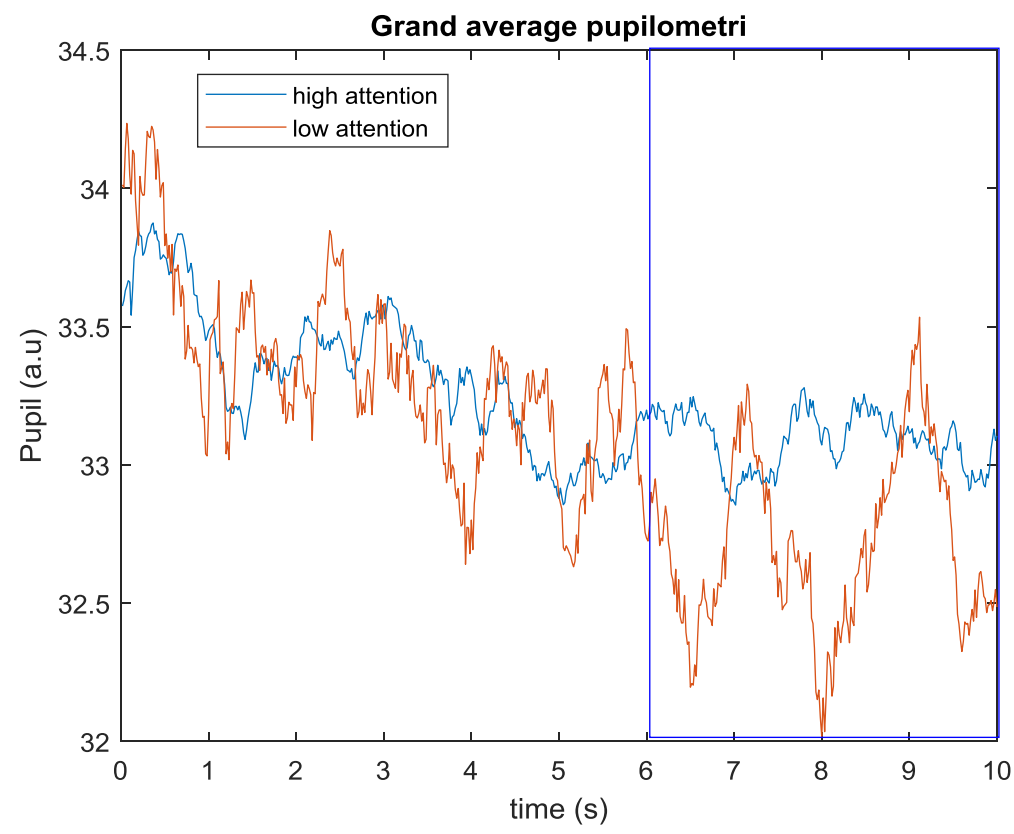

Gambar 7. Analisa temporal pupilometri n= 14

Penyelidikan lebih lanjut terkait perubahan ukuran pupil dilakukan dengan menghitung perbedaan aktivitas pupilometri pada awal 6 detik dan 4 detik terakhir tugas pengkodean dari Gambar 7 pada dua tingkat atensi ini. Tidak ada perbedaan signifikan $(\mathrm{P}=$ 0.4776) $(\mathrm{P}>0.05)$ dengan menggunakan Wilcoxon rank-sum test pada sinyal lanjutan di awal 6 detik. Tetapi saya menemukan ada perbedaan yang signifikan pada sinyal lanjutan dengan menggunakan uji Wilcoxon rank-sum test $(\mathrm{P}=3.8256 \mathrm{e}-41)(\mathrm{P}<0.05) 4$ detik terakhir. Tabel 1 menunjukkan rata-rata pupilometri tiap peserta berdasarkan tingkat atensi.

Table 1. Rerata ukuran pupilometri pada setiap partisipan

\begin{tabular}{|c|c|c|c|c|}
\hline & \multicolumn{2}{|c|}{ Enam detik awal } & \multicolumn{2}{c|}{ Empat detik terakhir } \\
\hline & Atensi tinggi & Atensi rendah & Atensi tinggi & Atensi rendah \\
\hline S1 & 31.83368 & 33.42625 & 31.04758 & 31.18264 \\
\hline S2 & 34.77668 & 32.40753 & 33.5032 & 30.27424 \\
\hline S3 & 23.33582 & 23.95336 & 24.35332 & 23.99374 \\
\hline S4 & 26.44845 & 26.01096 & 26.25718 & 25.31754 \\
\hline S5 & 33.18858 & 33.35039 & 33.25034 & 33.85547 \\
\hline S6 & 37.72262 & 38.13709 & 37.85865 & 37.77368 \\
\hline S7 & 34.00407 & 34.05662 & 33.61359 & 33.76792 \\
\hline S8 & 37.52127 & 36.83961 & 37.15663 & 35.11022 \\
\hline S9 & 36.4444 & 35.90752 & 36.19968 & 35.18421 \\
\hline S10 & 36.56941 & 37.23889 & 36.8433 & 37.48195 \\
\hline S11 & 32.62384 & 32.99973 & 32.09949 & 32.2347 \\
\hline S12 & 32.2439 & 30.8706 & 32.52735 & 30.82266 \\
\hline S13 & 31.88902 & 34.01617 & 30.58318 & 33.03103 \\
\hline S14 & 38.0648 & 37.46423 & 37.96614 & 37.89966 \\
\hline Average & 33.33333 & 33.33421 & 33.08997 & 32.70926 \\
\hline SD & 4.254170 & 4.150505 & 4.132913 & 4.074638 \\
\hline
\end{tabular}




\section{Pembahasan}

Dewan et al [25], juga menyebutkan metode dengan menggunakan data fisiologis seperti pergerakan mata, data neurologis cenderung tidak mengganggu peserta didik dalam proses deteksi atensi. Karena dalam penelitian ini tugas kognitif (cognitive tasks) memiliki beberapa tingkatan, pengaruh ukuran pupil terhadap level tugas kognitif juga dianalisa. Untuk mengetahui efek tingkatan tugas kognitif, penelitian ini hanya menganalisa atensi tinggi di setiap tugas karena sebagian besar data hasil laporan peserta (self assesment) melaporkan atensi tinggi terhadap tugas yang diberikan. Alhasil, data dengan atensi rendah tidak dapat digunakan. Analisis ANOVA dilakukan terhadap 13 partisipan dari data yang telah digunakan dalam penelitian ini (14 partisipan), satu partisipan dieksklusi karena pada satu kondisi tugas, self assessment partisipan menyebutkan bahwa partisipan hanya merasakan atensi yang rendah. Penelitian ini mendapatkan hasil $\mathrm{F}=0.13754$, $\mathrm{P}$-value 0.871978 di aritmatika dalam 4 digit, 5 digit, dan 6 digit. Rentang digit maju $\mathrm{F}=0.16545$, nilai-P 0.848148. Rentang digit mundur $\mathrm{F}=0,056075$, nilai-P 0,94555 . Tidak ada perbedaan yang signifikan pada setiap tugas dengan $\mathrm{P}>0,05$ serupa dengan publikasi sebelumnya [19]. Hal ini dapat terjadi karena meskipun tugas saya berisi banyak level, level tersebut tidak memerlukan usaha yang berbeda dan mudah untuk dilakukan. Peneliti lain menyebutkan bahwa setelah rentang 6 digit, pupilometri dewasa terus membesar dan anak-anak mulai mengerut [27]. Gambar 8 menunjukkan aktivitas pupilometri di setiap tugas.

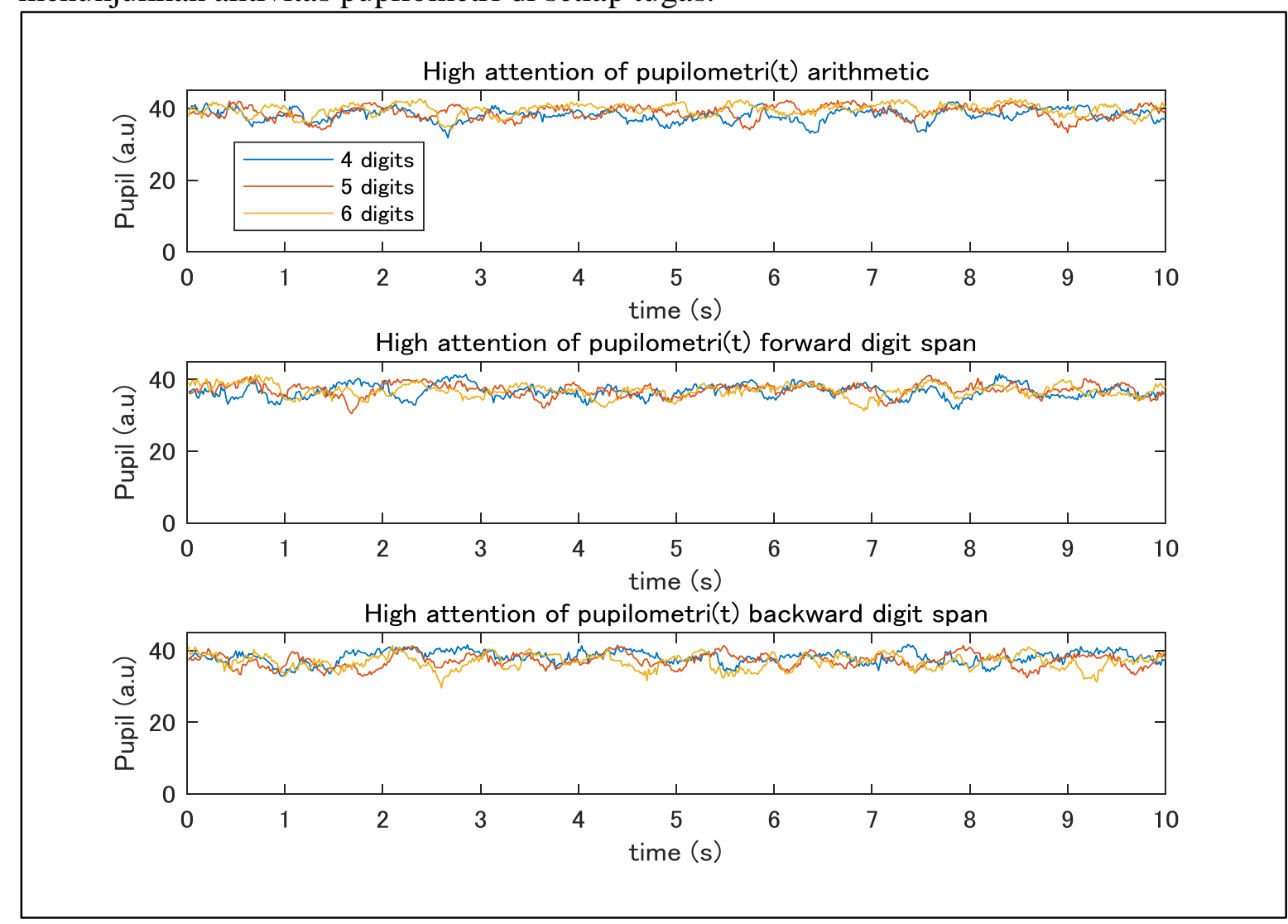

Gambar 8. Aktifitas pupil pada stimulasi yang berbeda

Heat map arah atensi tatapan dari semua peserta selama eksperimen dan menghasilkan gambar oleh "OGAMA" [28]. Posisi pandangan tidak digunakan dalam analisis data lebih lanjut untuk evaluasi tingkat atensi karena semua peserta melihat ke tengah monitor seperti yang ditunjukkan pada Gambar 9. Itu juga terjadi karena stimulus telah muncul di tengah monitor, sehingga menyelidiki status atensi berdasarkan posisi tatapan tidak tepat dalam penelitian ini. 


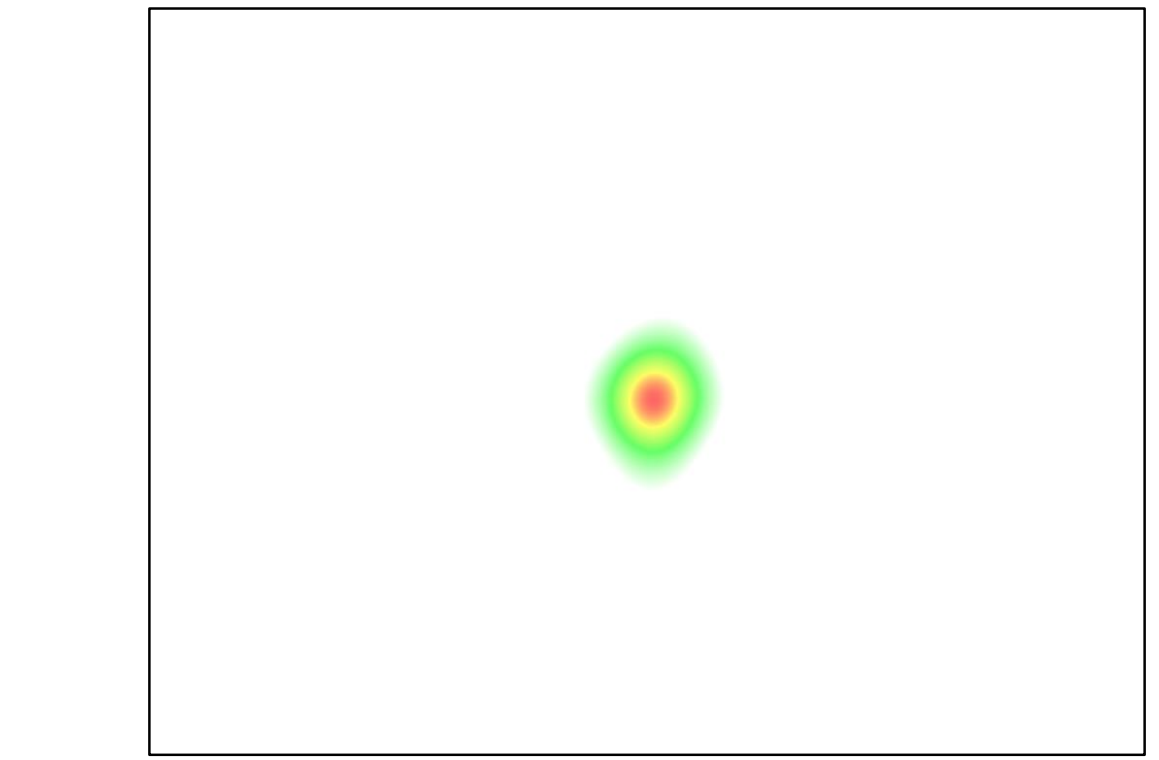

Gambar 9. Heatmap arah atensi tatapan dari semua peserta dianalisis dengan menggunakan Ogama

Dalam percobaan di dalam penelitian ini, waktu encoding adalah 10 detik. Eksperimen untuk atensi dengan waktu pengkodean setidaknya dalam kurun waktu 10 detik juga dilakukan oleh peneliti lain [29]. Mereka menyebutkan bahwa stimulasi 10 detik dapat dilakukan untuk penelitian atensi yang berkelanjutan (continuous attention). Dalam penelitian ini, waktu pengkodean 10 detik juga telah dipilih karena data ini akan digunakan sebagai pelabelan data untuk EEG, ECG, NIRS dimana fitur EKG umumnya dapat dianalisis setidaknya dalam 10 detik.

Meskipun sistem pelacakan mata ini memiliki frekuensi pengambilan sampel hingga $60 \mathrm{~Hz}$, ukuran pupil masih dapat dianalisis. Penelitian lain membandingkan kemampuan pelacakan mata dengan yang lain dan sampling frekuensi yang lebih tinggi, yang masih dapat diandalkan untuk pupilometri [23]. Dalam penelitian ini, analisis pupilometri dilakukan dalam analisis temporal. Penelitian ini menunjukkan bahwa pupilometri lebih tinggi pada atensi tinggi daripada atensi rendah. Kang et al [11], menyebutkan bahwa pelebaran pupil mampu mengindeks perubahan informasi terlepas dari perubahan visual tingkat rendah (pencahayaan). Mereka membuktikan bahwa perubahan dilatasi pupil bukan hanya karena perubahan cahaya tetapi juga karena perubahan informasi [12,30]. Pupilometri yang diperkenalkan dapat mencerminkan atensi visual. Jadi, fenomena perubahan aktivitas dalam studi ini bisa juga karena aktivitas atensi.

Secara spesifik, penelitian ini menunjukkan bahwa 4 detik terakhir memiliki perbedaan yang signifikan. Ini bisa terjadi karena pupilometri adalah korelasi dengan peristiwa temporal. Winn et al [31] menyebutkan bahwa waktu adalah bagian penting dari memahami upaya mendengarkan karena ucapan menuntut pengkodean pendengaran yang cepat serta pemrosesan kognitif yang didistribusikan dari waktu ke waktu, daripada digunakan sekaligus di akhir stimulus. Upaya tersebut mungkin tidak terdistribusi secara seragam pada peristiwa perseptual, dan pengukuran pupilometri memiliki manfaat untuk menunjukkan perubahan dilatasi pada penanda waktu yang berbeda. Dalam studi yang dilakukan oleh Koenig et al[24], terjadi peningkatan dilatasi murid pada tahap awal atensi untuk secara konsisten memperkuat isyarat belajar, sedangkan pada tahap selanjutnya pembelajaran ketika isyarat tersebut tidak menuntut banyak atensi, murid yang relatif lebih besar pelebaran diamati untuk isyarat ambigu atau tidak diperkuat. Respon murid dikaitkan dengan pergeseran strategis atensi dalam tugas yang diarahkan pada tujuan. Karatekin et al [2] mengukur pelebaran pupil yang lebih besar secara signifikan dalam kondisi atensi yang terbagi dalam percobaan tugas ganda yang dilakukan untuk membedakan akurasi dan efisiensi kinerja (dinyatakan sebagai "biaya kinerja itu dalam upaya mental"). 


\section{KESIMPULAN}

Pada penelitian ini kami meneliti efek dari tingkat atensi kepada perubahan aktifitas pupil. Kami menemukan bahwa ukuran pupil dengan atensi rendah lebih kecil daripada atensi tinggi, terutama dalam 4 detik terakhir. Penelitian ini dapat menjadi acuan awal untuk menggunakan ukuran pupil sebagai penanda atensi.

\section{REFERENSI}

[1] Granholm E, Steinhauer SR. Pupillometric measures of cognitive and emotional processes. Int J Psychophysiol. 2004 Mar;52(1): 1-6.DOI: 10.1016/j.ijpsycho.2003.12.001

[2] Karatekin, C., Marcus, D. J., \& Couperus, J. W. (2007). Regulation of cognitive resources during sustained attention and working memory in 10-year-olds and adults. Psychophysiology, 44, 128-144.

[3] Tsukahara, J. S., Harrison, T. L., \& Engle, R. W. (2016). The relationship between baseline pupil size and intelligence. Cognitive Psychology, 91, 109-123.

[4] Hartmann, M., \& Fischer, M. H. (2014). Pupillometry: The eyes shed fresh light on the mind. Current Biology, 24(7), R281-R282. https://doi.org/10.1016/j.cub.2014.02.028

[5] Geva, R., Zivan, M., Warsha, A., \& Olchik, D. (2013). Alerting, orienting or executive attention networks: Differential patters of pupil dilations. Frontiers in Behavioral Neuroscience, 7, 145.

[6] Unsworth, N., \& Robison, M. K. (2017a). A locus coeruleus-norepinephrine account of individual differences in working memory capacity and attention control. Psychonomic Bulletin \& Review, 24, 1282-1311.

[7] Unsworth, N., \& Robison, M. K. (2017b). Tracking working memory maintenance with pupillometry. Attention, Perception, \& Psychophysics, 1-24.

[8] Piquado, T., Isaacowitz, D., \& Wingfield, A. (2010). Pupillometry as a measure of cognitive effort in younger and older adults. Psychophysiology, 47, 560-569.

[9] Van den Brink RL, Murphy PR, Nieuwenhuis S (2016) Pupil Diameter Tracks Lapses of Attention. PLOS ONE 11(10): e0165274. https://doi.org/10.1371/journal.pone.0165274

[10] Smallwood J, Brown KS, Tipper C, Giesbrecht B, Franklin MS, Mrazek MD, et al. (2011) Pupillometric Evidence for the Decoupling of Attention from Perceptual Input during Offline Thought. PLoS ONE 6(3): e18298. https://doi.org/10.1371/journal.pone.0018298

[11] Kang, O. E., Huffer, K. E., \& Wheatley, T. P. (2014). Pupil Dilation Dynamics Track Attention to High-Level Information. PLoS ONE, 9(8), 102463. https://doi.org/10.1371/journal

[12] Naber, M., Alvarez, G.A., and Nakayama, K. (2013). Tracking the allocation of attention using human pupillary oscillations. Front.Psychol. 4, 919.

[13] Van der Wel, P. \& van Steenbergen, H. Psychon Bull Rev (2018) 25: 2005. https://doi.org/10.3758/s13423-018-1432-y

[14] Martínez-Sellés, M., Datino, T., Figueiras-Graillet, L. et al. Clinical Drug Investigation (2013) 33: 45. https://doi.org/10.1007/s40261-012-0032-2

[15] De Oliveira, R.A.M.; Araújo, L.F.; De Figueiredo, R.C.; Goulart, A.C.; Schmidt, M.I.; Barreto, S.M.; Ribeiro, A.L.P. (2017). Coffee Consumption and Heart Rate Variability: The Brazilian Longitudinal Study of Adult Health (ELSA-Brasil) Cohort Study. Nutrients 2017, 9, 741.

[16] Jensen, A. R., \& Figueroa, R. A. (1975). Forward and backward digit span interaction with race and IQ: Predictions from Jensen's theory [abstract]. Journal of Educational Psychology, 67(6), 882-893

[17] Cullum, C. M. (1998). Neuropsychological Assessment of Adults. In Neuropsychology (pp. 357-378). https://doi.org/10.1007/978-1-4899-1950-2_17 
[18] Berka, C., Levendowski, D. J., Lumicao, M. N., Yau, A., Davis, G., Zivkovic, V. T., ... Craven, P. L. (2007). EEG Correlates of Task Engagement and Mental Workload in Vigilance, Learning, and Memory Tasks.

[19] Zennifa, F., Ageno, S., Hatano, S., \& Iramina, K. (2018). Hybrid System for Engagement Recognition during Cognitive Tasks Using a CFS + KNN Algorithm. Sensors (Basel, Switzerland), 18(11). https://doi.org/10.3390/s18113691

[20] Zennifa, F. (2019). Quantitative Formula of Blink Rates-Pupillometry for Attention Level Detection in Supervised Machine Learning. IEEE access 7, 96263-96271.

[21] Rosenthal, E. N., Riccio, C. A., Gsanger, K. M., \& Jarratt, K. P. (2006). Digit Span components as predictors of attention problems and executive functioning in children. Archives of Clinical Neuropsychology, 21, 131-139. https://doi.org/10.1016/j.acn.2005.08.004

[22] Mathôt, S. 2018 Pupillometry: Psychology, Physiology, and Function. Journal of Cognition, 1(1): 16, pp. 1-23, DOI: https://doi.org/10.5334/joc.18

[23] Dalmaijer, E. S. (n.d.). Is the low-cost EyeTribe eye tracker any good for research? https://doi.org/10.7287/peeri.preprints.585v1

[24] Koenig S., Uengoer M., Lachnit H. (2017) Pupil dilation indicates the coding of past prediction errors: Evidence for attentional learning theory. Psychophysiology 55(4): e13020 doi:10.1111/psyp.13020

[25] Dewan, M. A. A., Murshed, M., \& Lin, F. (2019). Engagement detection in online learning: a review. Smart Learning Environments, 6(1), 1-20. https://doi.org/10.1186/s40561-018-0080-Z

[26] Whitehill, J., Serpell, Z., Lin, Y. C., Foster, A., \& Movellan, J. R. (2014). The faces of engagement: Automatic recognition of student engagement from facial expressions. IEEE Transactions on Affective Computing, 5(1), 86-98. https://doi.org/10.1109/TAFFC.2014.2316163

[27] Johnson, E. L., Miller Singley, A. T., Peckham, A. D., Johnson, S. L., \& Bunge, S. A. (2014). Task-evoked pupillometry provides a window into the development of shortterm memory capacity. Frontiers in Psychology, 5(MAR), 1-8. https://doi.org/10.3389/fpsyg.2014.00218

[28] Voßkühler, A., (2009). OGAMA Description (for Version 2.5). A software to record, analyze and visualize gaze and mouse movements in screen based environments.

[29] Langner R, Eickhoff SB. Sustaining attention to simple tasks: a meta-analytic review of the neural mechanisms of vigilant attention. Psychol Bull. 2013 Jul; 139(4):870-900. doi: 10.1037/a0030694. Epub 2012 Nov 19.

[30] Naber, M., Alvarez, G.A., and Nakayama, K. (2013). Tracking the allocation of attention using human pupillary oscillations. Front.Psychol. 4, 919

[31] Winn, M. B., Wendt, D., Koelewijn, T., \& Kuchinsky, S. E. (2018). Best Practices and Advice for Using Pupillometry to Measure Listening Effort: An Introduction for Those Who Want to Get Started. Trends in hearing, 22, 2331216518800869. doi:10.1177/2331216518800869 